\title{
Impact of urothelial carcinoma with divergent differentiation on tumor stage
}

\author{
Chalise $\mathrm{S}^{1}$, Jha $\mathrm{A}^{2}$, Neupane $\mathrm{PR}^{3}$, Pradhan $\mathrm{SB}^{1}$, Pathak $\mathrm{R}^{4}$ \\ ${ }^{1}$ Departmant of Pathology, Kathmandu Medical College, Sinamangal, Nepal. \\ ${ }^{2}$ Department of Pathology, Institute of Medicine, Maharajgunj, Nepal. \\ ${ }^{3}$ Departmant of Surgery, Bhaktapur Cancer Hospital, Bhaktapur, Nepal \\ ${ }^{4}$ Department of Pathology, Nepal Medical College, Jorpati, Nepal.
}

\section{Keywords: \\ Urothelial carcinoma; Divergent differentiation; Tumor stage}

\begin{abstract}
Background: Urinary bladder cancer is classified as urothelial or non-urothelial. Ninenty percent of bladder cancer are urothelial and has propensity for divergent differentiation. Squamous differentiation is associated with unfavourable prognostic features. The aim of this study is to determine the significance of urothelial carcinoma with divergent differentiation in relation to tumor stage and lymphovascular as well as perineural invasion in radical cystectomy and partial cystectomy specimen.
\end{abstract}

Materials and Methods: This prospective study was done among 51 patients who underwent radical cystectomy or partial cystectomy at Bhaktapur Cancer Hospital from 1st August 2013 to 31st December 2015. Received specimen was grossed following standard protocol and histopathological evaluation was done in relation to tumor type, depth of invasion, Lymphovascular and perineural invasion.

RESULTS: Pure urothelial carcinoma comprises $47.1 \%$ of cases. Among the divergent differentiation, urothelial carcinoma with squamous differentiation was the commonest one (39.2\%) followed by glandular differentiation $(5.9 \%)$, sarcomatoid differentiation $(3.9 \%)$, clear cell variant $(2.0 \%)$ and squamous along with sarcomatoid variant $(2.0 \%)$. Statistical significant correlation was found between urothelial carcinoma with divergent differentiation and tumor stage $(\mathrm{p}<0.012)$. Statistically significant correlation was also found between urothelial carcinoma with divergent differentiation and lymphovascular invasion $(\mathrm{p}=0.012)$ as well as perineural invasion $(\mathrm{p}=0.037)$.

CONCLUSION: Most common divergent differentiation was squamous differentiation. Urothelial carcinoma with divergent differentiation was associated with higher stage and lymphovascular as well as perineural invasion. So it is mandatory to search for the divergent differentiation in urothelial carcinoma as this may be associated with unfavourable prognosis.

\section{INTRODUCTION}

Urinary bladder cancer is the 7 th most common cancer

\section{Correspondence:}

Dr. Sanat Chalise, $M D$

Department of Pathology, Kathmandu Medical College, Kathmandu, Nepal and Bhaktapur Cancer hospital, Bhaktapur, Nepal

E-mail:sanatchalise@hotmail.com,sanat_chalise@yahoo.com worldwide, with an estimated 260000 new cases occurring each year in men and 76000 in women. ${ }^{1}$ The prevalence of these tumor is higher in developed countries as compared to developing countries. In the United States alone, an estimated 70980 new cases were diagnosed with an estimated 14330 deaths in $2009 .^{2}$

The most common type is urothelial carcinoma derived 
Table 1: Frequency of urothelial carcinoma

\begin{tabular}{lc}
\hline Variants of urothelial carcinoma & No (\%) \\
$\begin{array}{l}\text { Infiltrating urothelial carcinoma } \\
\begin{array}{l}\text { Infiltrating urothelial carcinoma with squamous } \\
\text { differentiation }\end{array}\end{array}$ & $24(47.1)$ \\
\hline $\begin{array}{l}\text { Infiltrating urothelial carcinoma with glandular } \\
\text { differentiation }\end{array}$ & $3(5.9)$ \\
$\begin{array}{l}\text { Infiltrating urothelial carcinoma with sarcomatoid } \\
\text { variant }\end{array}$ & $2(3.9)$ \\
$\begin{array}{l}\text { Infiltrating urothelial carcinoma with clear cell variant } \\
\text { Infiltrating urothelial carcinoma with squamous and } \\
\text { sarcomatoid variant }\end{array}$ & $1(2.0)$ \\
Total & $1(2.0)$ \\
\hline
\end{tabular}

from urothelium which constitute more than $90 \%$ of bladder cancer in America, France and Italy. ${ }^{1}$ Urothelial carcinoma is known to show variant histological features, otherwise known as divergent differentiation, with an estimate ranging from $7 \%$ to $81 \%$ in a series specifically reporting the differentiation patterns of urothelial cancer. ${ }^{3}$

The recognization of histological variants in urothelial neoplasm is important because some type may be associated with different clinical outcomes, some may have different therapeutic approach and awareness of unusual pattern may be critical in avoiding diagnostic misinterpretation. ${ }^{4}$

Squamous differentiation is the most important histological variant of urothelial carcinoma followed by glandular differentiation. ${ }^{5}$ Upto $60 \%$ of tumor exhibit squamous differentiation and approximately $10 \%$ of urothelial carcinoma contains foci of glandular differentiation. ${ }^{4}$ Radical cystectomy with bilateral pelvic lymphnode dissection is currently the gold standard treatment for muscle invasive urinary bladder carcinoma. Unfortunately, $40 \%$ of patient with organ confined disease at the time of cystectomy urinary bladder subsequently suffer recurrence. ${ }^{6}$

In a large study done by Wasco and colleague, it was found that urothelial carcinoma with divergent differentiation were most likely to be invasive $(p<0.001) .{ }^{3}$ The aim of the present study is to evaluate the urothelial carcinoma and its differentiation in radical cystectomy and partial cystectomy specimens and correlate the divergent differentiation with tumor stage as well as lymphovascular and perineural invasions.

\section{MATERIALS AND METHODS}

This is a prospective study done in the Department of Pathology, Bhaktapur Cancer Hospital. A total of 51 patients who underwent radical cystectomy and partial cystectomy with bilateral pelvic lymphnode dissection during the period of 1st August 2013 to 31st December 2015 were included in the study. Prior to study permission from ethical review committee has been obtained.
The received specimens were grossed and processed using standard technique. Tumor type, differentiation, depth of invasion, lymphovascular invasion and perineural invasion were assessed. Tumor staging and grading were done according to American joint committee of cancer (AJCC). Statistical analysis was done using Pearson chi-square test and statistically significant value was set at $\mathrm{p}<0.05$.

\section{RESULTS}

The study comprises of 51 patient of which 41 (80.4\%) were male and $10(9.6 \%)$ were female, treated with radical cystectomy $(n=43)$ and partial cystectomy $(n=8)$ with pelvic lymphnode dissection. The age of the patient ranged from 45-85 years with mean age of 66.1 years.

Pure urothelial carcinoma was diagnosed in 24 patients (47.1\%). Among the divergent differentiation, squamous differentiation was diagnosed in 20 patient $(39.2 \%)$ followed by glandular differentiation in 3 patient $(5.9 \%)$, sarcomatoid variant in 2 patient (3.9\%), clear cell variant in 1 patient $(2 \%)$ and squamous along with sarcomatoid variant in 1 patient (2\%) as shown in Table 1 and Figure 1-3.

Urothelial carcinoma with divergent differentiation were staged as pT3a in $25.4 \%$ of cases or even higher stage (Table 2 and 3). Using pearson chi-square test, statistical significant correlation was obtained between UC with divergent differentiation and tumor stage $(\mathrm{p}=0.012)$ which signifies that divergent differentiation is associated with higher stage (Table 4).

Lymphovascular and perineural invasion were present in $64.7 \%$ of cases. Most of the cases with divergent differentiation were positive for lymphovascular and perineural invasion (Table 5 and 6). Statistical significant correlation was also obtained between UC with divergent differentiation and lymphovascular as well as perineural invasion (Table 7 and 8)

\section{DISCUSSION}

Urothelial carcinoma are the commonest urothelial neoplasm and have a great capacity for divergent differentiation. Squamous differentiation is the commonest divergent differentiation. ${ }^{7}$ Pathological stage and lymphnode status are the common primary prognostic factors after radical cystectomy as they are the strong predictors for the survival. ${ }^{8}$ The clinical significance of squamous differentiation remains uncertain, but seems to be an unfavourable prognostic features predicting local recurrence after cystectomy. ${ }^{7}$

In this study, the mean age was found to be 66.1 of which $41(80.4 \%)$ were male and $10(19.6 \%)$ were female. Among 51 cases, $27(52.9 \%)$ had a infiltrating carcinoma with divergent differentiation, the commonest being squamous differentiation (39.2\%) followed by glandular differentiation 
Table 2: Distribution of histopathological types of urothelial carcinoma and tumor stage

\begin{tabular}{|c|c|c|c|c|c|c|c|c|}
\hline Tumor type & & & & Tumor Stage & & & & Total \\
\hline & T1 & T2a & T2b & T3a & T3b & T4a & T4b & \\
\hline $\begin{array}{l}\text { Infiltrating urothelial } \\
\text { carcinoma }\end{array}$ & 5 & 8 & 5 & 5 & 1 & 0 & 0 & $24(47.1 \%)$ \\
\hline $\begin{array}{l}\text { Infiltrating } \\
\text { urothelial carcinoma } \\
\text { with squamous } \\
\text { differentiation }\end{array}$ & 0 & 0 & 1 & 12 & 3 & 3 & 1 & $20(39.2 \%)$ \\
\hline $\begin{array}{l}\text { Infiltrating } \\
\text { urothelial carcinoma } \\
\text { with glandular } \\
\text { differentiation }\end{array}$ & 1 & 0 & 1 & 1 & 0 & 0 & 0 & $3(5.9 \%)$ \\
\hline $\begin{array}{l}\text { Infiltrating urothelial } \\
\text { carcinoma with } \\
\text { sarcomatoid variant }\end{array}$ & 0 & 0 & 0 & 0 & 1 & 1 & 0 & $2(3.9 \%)$ \\
\hline $\begin{array}{l}\text { Infiltrating urothelial } \\
\text { carcinoma with clear } \\
\text { cell variant }\end{array}$ & 0 & 0 & 1 & 0 & 0 & 0 & 0 & $1(2.0 \%)$ \\
\hline $\begin{array}{l}\text { Infiltrating urothelial } \\
\text { carcinoma with } \\
\text { squamous and } \\
\text { sarcomatoid variant }\end{array}$ & 0 & 0 & 0 & 0 & 0 & 1 & 0 & $1(2.0 \%)$ \\
\hline Total & $6(11.8 \%)$ & $8(15.7 \%)$ & $8(15.7 \%)$ & $18(35.3 \%)$ & $5(9.8 \%)$ & $5(9.8 \%)$ & $1(2 \%)$ & $51(100 \%)$ \\
\hline
\end{tabular}

Table 3: Frequency of urothelial carcinoma with divergent differentiation and tumor stage

\begin{tabular}{|c|c|c|c|c|c|c|c|c|}
\hline Tumor type & & & & Tumor Stage & & & & Total \\
\hline & T1 & T2a & T2b & T3a & T3b & T4a & T4b & \\
\hline $\begin{array}{l}\text { Infiltrating } \\
\text { urothelial carcinoma } \\
\text { with squamous } \\
\text { differentiation }\end{array}$ & 0 & 0 & 1 & 12 & 3 & 3 & 1 & $20(39.2 \%)$ \\
\hline $\begin{array}{l}\text { Infiltrating } \\
\text { urothelial carcinoma } \\
\text { with glandular } \\
\text { differentiation }\end{array}$ & 1 & 0 & 1 & 1 & 0 & 0 & 0 & $3(5.9 \%)$ \\
\hline $\begin{array}{l}\text { Infiltrating urothelial } \\
\text { carcinoma with } \\
\text { sarcomatoid variant }\end{array}$ & 0 & 0 & 0 & 0 & 1 & 1 & 0 & $2(3.9 \%)$ \\
\hline $\begin{array}{l}\text { Infiltrating urothelial } \\
\text { carcinoma with clear } \\
\text { cell variant }\end{array}$ & 0 & 0 & 1 & 0 & 0 & 0 & 0 & $1(2.0 \%)$ \\
\hline $\begin{array}{l}\text { Infiltrating urothelial } \\
\text { carcinoma with } \\
\text { squamous and } \\
\text { sarcomatoid variant }\end{array}$ & 0 & 0 & 0 & 0 & 0 & 1 & 0 & $1(2.0 \%)$ \\
\hline Total & $1(1.9 \%)$ & $0(0 \%)$ & $3(5.8 \%)$ & $13(25.4 \%)$ & $4(7.8 \%)$ & $5(9.8 \%)$ & $1(1.9 \%)$ & $27(100 \%)$ \\
\hline
\end{tabular}

Table 4: Correlation between urothelial carcinoma with divergent differentiation and tumor stage

\begin{tabular}{|c|c|c|}
\hline \multirow{3}{*}{ Urothelial carcinoma with divergent differentiation and tumor stage } & \multicolumn{2}{|c|}{ Pearson Chi-Square } \\
\hline & value & $\begin{array}{l}\text { Asymp. Sig. (2-sided) P } \\
\text { Value }\end{array}$ \\
\hline & 49.998 & 0.012 \\
\hline
\end{tabular}


Table 5: Frequency of urothelial carcinoma associated with lymphovascular invasion

\begin{tabular}{lccc}
\hline \multirow{2}{*}{ Tumor type } & \multicolumn{2}{c}{ Lymphovascular invasion } & \multirow{2}{*}{ Total } \\
\cline { 2 - 3 } & Positive & Negative & $24(47.1 \%)$ \\
\hline Infiltrating urothelial carcinoma & 9 & 15 & $20(39.2 \%)$ \\
\hline Infiltrating urothelial carcinoma with squamous differentiation & 16 & 4 & $3(5.9 \%)$ \\
Infiltrating urothelial carcinoma with glandular differentiation & 1 & 2 & $2(3.9 \%)$ \\
\hline Infiltrating urothelial carcinoma with sarcomatoid variant & 2 & 0 & $1(2.0 \%)$ \\
Infiltrating urothelial carcinoma with clear cell variant & 1 & 0 & $1(2.0 \%)$ \\
Infiltrating urothelial carcinoma with squamous and sarcomatoid variant & 1 & 0 & $\mathbf{5 1 ( 1 0 0 \% )}$ \\
Total & $\mathbf{3 3 ( 6 4 . 7 \% )}$ & $\mathbf{1 8}(\mathbf{3 5 . 3 \% )}$ &
\end{tabular}

Table 6: Correlation between urothelial carcinoma with divergent differentiation and lymphovascular invasion

\begin{tabular}{|c|c|c|}
\hline \multirow{3}{*}{$\begin{array}{l}\text { Urothelial carcinoma with divergent differentiation and lymphovascular } \\
\text { invasion }\end{array}$} & \multicolumn{2}{|c|}{ Pearson Chi-Square } \\
\hline & value & $\begin{array}{l}\text { Asymp. Sig. (2-sided) P } \\
\text { Value }\end{array}$ \\
\hline & 11.813 & 0.037 \\
\hline
\end{tabular}

Table 7: Frequency of urothelial carcinoma associated with perineural invasion

\begin{tabular}{lccc}
\hline \multirow{2}{*}{ Tumor type } & \multicolumn{2}{c}{ Perineural invasion } & Total \\
\cline { 2 - 3 } & Positive & Negative & $24(47.1 \%)$ \\
\hline Infiltrating urothelial carcinoma & 9 & 15 & $20(39.2 \%)$ \\
Infiltrating urothelial carcinoma with squamous differentiation & 19 & 1 & $3(5.9 \%)$ \\
\hline Infiltrating urothelial carcinoma with glandular differentiation & 1 & 2 & $2(3.9 \%)$ \\
\hline Infiltrating urothelial carcinoma with sarcomatoid variant & 2 & 0 & $1(2.0 \%)$ \\
Infiltrating urothelial carcinoma with clear cell variant & 1 & 0 & $1(2.0 \%)$ \\
Infiltrating urothelial carcinoma with squamous and sarcomatoid variant & 1 & 0 & $\mathbf{5 1 ( 1 0 0 \% )}$ \\
Total & $\mathbf{3 3 ( 6 4 . 7 \% )}$ & $\mathbf{1 8 ( 3 5 . 3 \% )}$ &
\end{tabular}

Table 8: Correlation between urothelial carcinoma with divergent differentiation and perineural invasion

\begin{tabular}{|c|c|c|}
\hline \multirow{3}{*}{ Urothelial carcinoma with divergent differentiation and perineural invasion } & \multicolumn{2}{|c|}{ Pearson Chi-Square } \\
\hline & value & $\begin{array}{l}\text { Asymp. Sig. (2-sided) P } \\
\text { Value }\end{array}$ \\
\hline & 19.290 & 0.002 \\
\hline
\end{tabular}

(5.9\%). Kucuk $\mathrm{U}$ et $\mathrm{al}^{6}$ in their study found $45.2 \%$ of cases having divergent differentiation of which the commonest differentiation found was squamous differentiation (18.4\%). In the study done by Kim SP et $\mathrm{al}^{9}$ and Mitra AP et $\mathrm{al}^{10}$, squamous differentiation was found to be the commonest divergent differentiation. Antunes AA et $\mathrm{al}^{11}$ in their study found, $22.1 \%$ of cases with squamous differentiation.

The present study found that patient with divergent differentiation presented stage pT1, pT2a, pT2b, pT3a, pT3b, pT4a, pT4b in $1.9 \%, 0 \%, 5.8 \%, 25.4 \%, 7.8 \%, 9.8 \%$ and $1.9 \%$ respectively. Most of the cases with divergent differentiation were staged as pT3a. Using Pearson chisquare test, significant result was obtained between divergent tumor differentiation and tumor stage $(p=0.012)$, which signifies that the tumor stage was high when there is divergent differentiation. Similarly Lee YJ et $\mathrm{al}^{5}$ in their their study found significant correlation $(\mathrm{p}<0.001)$ between Urothelial carcinoma with squamous and or glandular differentiation and tumor stage. Kim SP et $\mathrm{al}^{9}$ also concluded that Urothelial carcinoma with squamous and or glandular differentiation had higher stage as compared to the pure Urothelial carcinoma and in their study, $70 \%$ of the cases were pT3-T4 tumors. Similar result was obtained from the study done by Xylinas E et $\mathrm{al}^{12}$, they also found significant correlation $(\mathrm{p}<0.01)$ between histological UC variants and tumor stage. In concordance to the present study, LopezBeltran $\mathrm{A}_{\text {et }} \mathrm{al}^{7}$ in their study concluded higher tumor stage and grade in the urinary bladder tumor with squamous differentiation. Similar to our study, Autunes AA et al ${ }^{11}$ 


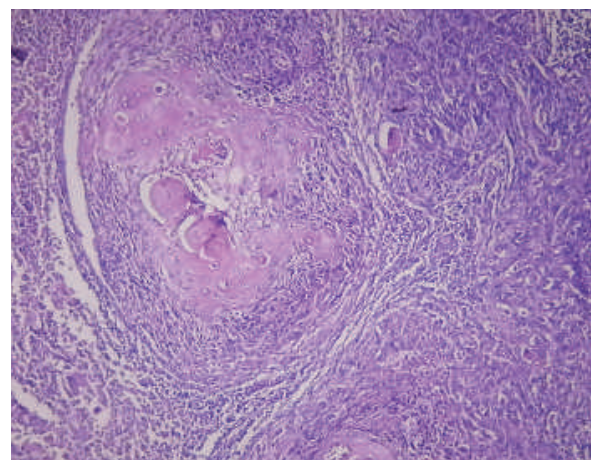

Figure 1: Urothelial carcinoma with squamous differentiation showing keratin pearls and intercellular bridges $(H \&$ E stain, X100).

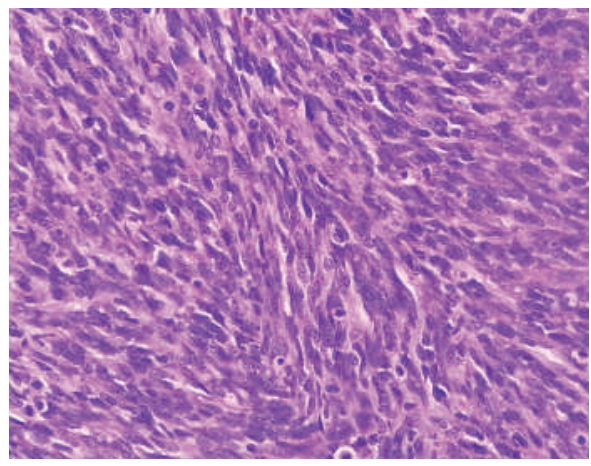

Figure 3: Urothelial carcinoma with sarcomatoid differentiation showing fascicles of spindle shaped cells. (H\& E stain, X400).

also found squamous differentiation as a commonest tumor and significant correlation was obtained between UC with squamous differentiation and tumor stage $(\mathrm{p}=0.031)$.

Lymphovascular and perineural invasion were present in $64.7 \%$ of cases. Most of the cases with divergent differentiation were positive for lymphovascular and perineural invasion. Statistical significant correlation was obtained $(p<0.05)$ between Urothelial carcinoma with divergent differentiation and lymphovascular as well as perineural invasion in the current study which was similar to the study done by Brunocilla E 13, Lee YJ et al5, Kim SP et al9 and Antunes AA et al11 in their study also found significant statistical correlation between Urothelial carcinoma with divergent differentiation and lymphovascular as well as perineural invasion. In contrast to our study, Kucuk U et al6 does not found significant correlation between divergent differentiation and lymphovascular invasion.

\section{CONCLUSION}

Squamous differentiation is the commonest divergent differentiation. Patient with divergent differentiation is associated with higher stage as well as lymphovascular and perineural invasion. Thus extensive search for the divergent differentiation should be done by the pathologist as these

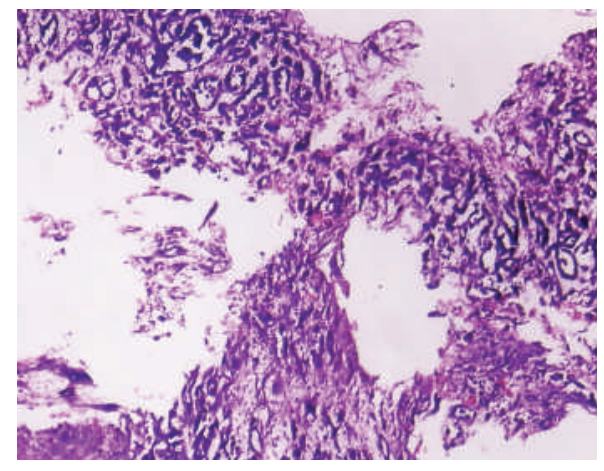

Figure 2: Urothelial carcinoma with glandular differentiation, showing wellformed glands ( $H \&$ E stain, X100).

factors which may be associated with adverse clinical outcomes of the patient should be taken into consideration in treatment planning.

\section{REFERENCES}

1. Lopez-Beltran A, Sauter G, Gasser $T$ et al: Infiltrating urothelial carcinoma, In: Eble JN, Sauter G, Epstein JI, sasterhenn IA (eds). World Health Organization classification of tumours Pathology and genetics tumours of the urinary system and male genital organs. IARC Press: Lyon; 2004. pp 93-109. Crossref

2. Vaidya S, Lakhey M, KC S, Hirachand S. Urothelial tumors of the urinary bladder: A histopathological study of cystoscopic biopsies. J Nepal Medical Association 2013;52:475-8. Crossref

3. Chalasani V, Chin JL, Izawa JI. Histologic variants of urothelial bladder cancer and non urothelial histology in bladder cancer. CUAJ 2009;3:193-8.

4. Amin MB. Histological variants of urothelial carcinoma: diagnostic, therapeutic and prognostic implications. Modern Pathol 2009;26:96118. Crossref

5. Lee YJ, Moon KC, Jeong CW, Kwak C, Kim HH, Ku JHl. Impact of squamous and glandular differentiation on oncologic outcomes in upper and lower tract urothelial carcinoma. PLOS ONE 2014;9:1-8. Crossref

6. Kucuk U, Pala EE, Cakir E et al. Clinical, demographic and histopathological prognostic factors for urothelial carcinoma of the bladder. Central Europian Journal of Urology 2015;68:30-6. Crossref

7. Lopez-Beltran A, Requena MJ, Alvaraz-Kindelan J, Quintero A, Blanca A, Montironi R. Squamous differentiation in primary urothelial carcinoma of the urinary tract as seen by MAC387 immunohistochemistry. J Clin Pathol 2007;60:332-5. Crossref

8. Seraj MJ, Thomas AR, Chin JL, Theodorescu D. Molecular determination of perivesical and lymphnode metastasis after radical cystectomy for urothelial carcinoma of the bladder. Clinical cancer research 2001;7:1516-22. Crossref 
9. Kim Sp, Frank I, Cheville JC et al. The impact of squamous and glandular differentiation on survival after radical cystectomy for urothelial carcinoma. J Urol 2012;188:405-9. Crossref

10. Mitra AP, Bartsch CC, Bartsch JR, Miranda G, Skinner EC, Daneshmand S. Does presence of squamous and glandular differentiation in urothelial carcinoma of the bladder at cystectomy portend poor prognosis? An intensive case-control analysis. Urol Oncol. 2014;32:117-27. Crossref

11. Antunes AA, Nesrallah LJ, Dall'oglio MF et al. The role of squamous differentiation with transitional cell carcinoma of the bladder treated with radical cystectomy. International Braz J Urol 2007;33:339-46. Crossref
12. Xylinas $\mathrm{E}$, Rink $\mathrm{M}$, Robinson $\mathrm{BD}$ et al. Impact of histological variants on oncological outcomes of patients with urothelial carcinoma of the bladder treated with radical cystectomy. European Journal of Cancer 2013;49:1889-97. Crossref

13. Brunocilla E, Pernetti R, Martorana G. The prognostic role of lymphovascular invasion in urothelial carcinoma of upper and lower urinary tract. Anticancer research 2011;31:3503-6. Crossref 